Emergency Assessment of Mount St. Helens Post-eruption Flood Hazards, Toutle and Cowlitz Rivers, Washington

GEOLOGICAL SURVEY CIRCULAR $\div 850$ - 


\section{METRIC CONVERSION FACTORS}

\section{Multiply}

foot (ft)

cubic yard $\left(\mathrm{yd}^{3}\right)$

mile (mi)

square mile $\left(\mathrm{mi}^{2}\right)$

cubic foot per second $\left(\mathrm{ft}^{3} / \mathrm{sec}\right)$
By

0.3048

0.7646

1.609

2.590

0.02832
To obtain

meter $(\mathrm{m})$

cubic meter $\left(\mathrm{m}^{3}\right)$

kilometer $(\mathrm{km})$

square kilometer $\left(\mathrm{km}^{2}\right)$

Cubic meter per second $\left(\mathrm{m}^{3} / \mathrm{s}\right)$

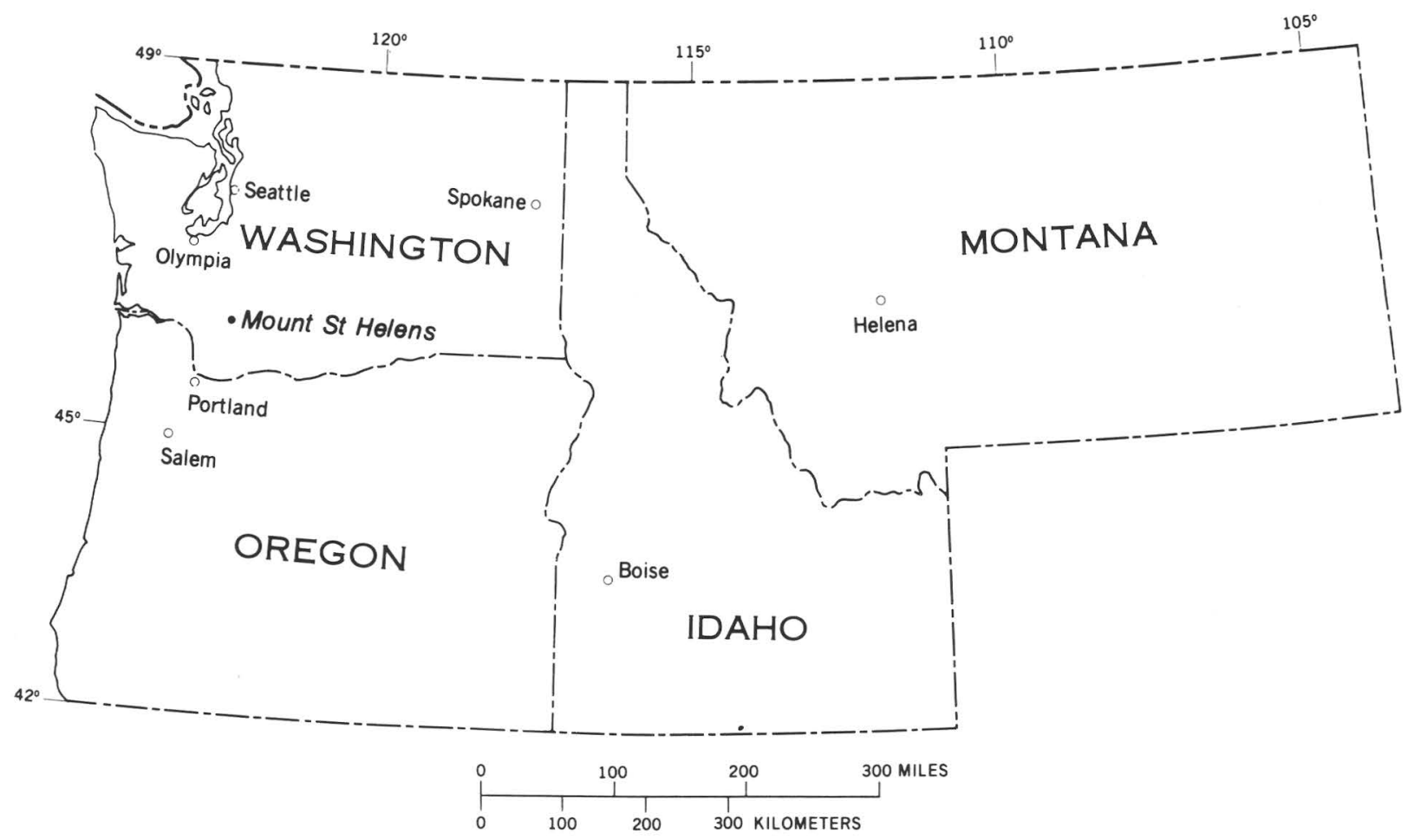

COVER: North Fork Toutle River, June 30, 1980. Volcanic mud flow breccia and debris from the May 18, 1980, eruption of Mount St. Helens (in upper right) are as much as several hundred feet thick in the reach shown. Photograph by Austin Post, U.S. Geological Survey. 


\section{Emergency Assessment of Mount St. Helens Post-eruption Flood Hazards, Toutle and Cowlitz Rivers, Washington}

By M. E. Jennings, V. R. Schneider, and P. E. Smith 
United States Department of the Interior

JAMES G. WATT, Secretary

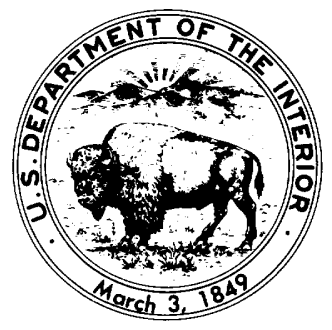

\section{Geological Survey}

Doyle G. Frederick, Acting Director

Library of Congress No. 81-600131

Free on application to Distribution Branch, Text Products Section, U. S. Geological Survey, 604 South Pickett Street, Alexandria, VA 22304 


\section{FOREWORD}

On May 18, 1980, after more than a month of earthquakes and eruptions, Mount St. Helens, in southwestern Washington, exploded in a volcanic eruption more violent than any in the conterminous. United States during the 20th century. A lateral blast of hot gas and rock particles devastated an area of about 150 square miles on the northern side of the mountain knocking down trees to a distance of 15 miles. Several minutes later, a giant ash cloud rose to about 60,000 feet. Winds then carried the ash cloud across the United States, with heavy fallout and deposition in eastern Washington and parts of Idaho and Montana. Earlier, smaller eruptions deposited ash in western Washington and parts of Oregon and Canada.

The hydrologic effects of the May 18 eruption have been both widespread and intense. During the eruption, a massive debris avalanche moved down the north flank of the volcano depositing about 3 billion cubic yards of rock, ice, and other materials in the upper 17 miles of the North Folk Toutle River valley. The debris deposits are about 600 feet thick in the upper reaches of the valley. Following the avalanche, runoff from the melted glaciers and snow, and possible outflow from Spirit Lake, caused an extraordinary mudflow in the North Fork Toutle River. The mudflow shattered and uprooted thousands of trees, destroyed most of the local bridges, and deposited an estimated 25,000 acre-feet of sediment in the Cowlitz River channel. A considerable amount of additional sediment was conveyed through the lower Cowlitz into the Columbia River where it was deposited and formed a shoal that blocked the shipping channel. Mudflows also occurred in the South Fork Toutle River and in tributaries on the east flank of Mount St. Helens which enter Swift Reservoir.

As part of a concerted Geological Survey effort to study the volcanic event and to identify potential hazards, Survey hydrologists have mounted an intensive program to document the hydrologic effects of the eruptions. The major initial hydrologic findings are reported in this circular series. Quick, useful assessment was made possible only because the Survey has long conducted extensive water-resources investigations in the affected areas of Washington, Oregon, and Idaho. Hence, there was a well-defined basis for identification and documentation of the types and magnitudes of hydrologic changes.

The Geological Survey Circular 850, "Hydrologic Effects of the Eruptions of Mount St. Helens, Washington, 1980," consists of individually published short chapters that emphasize data collection activities, field observations, and initial comparisons of preand post-eruption conditions. The series will cover hydrologic events occurring on May 18 in the Toutle and Cowlitz River; physical alteration of the Toutle River system; the chemical and physical quality of precipitation, streams, and lakes affected by volcanic ash fall; ash-leaching studies; and Mount St. Helens glaciers.

\section{Doyle A. Frederice}

Doyle G. Frederick Acting Director 



\section{CONTENTS}

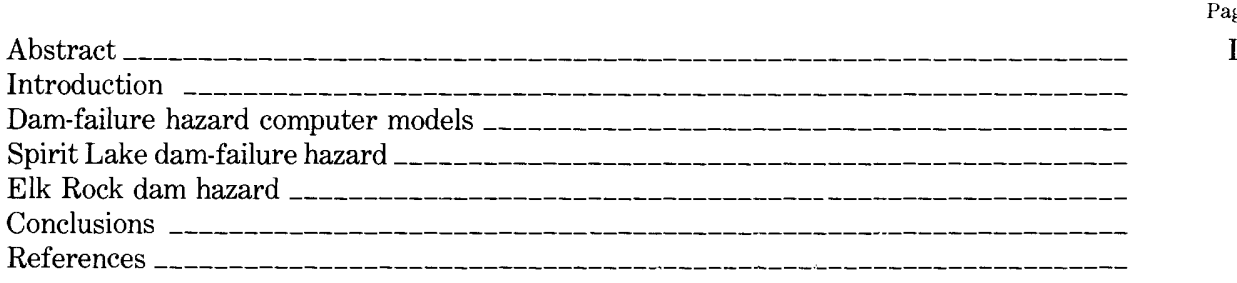

Page

1

1

3

6

7

7

\section{ILLUSTRATIONS}

Figure 1. The Mount St. Helens area

2. Approximate pre- and post-eruption bed profiles of the North Fork Toutle and Toutle Rivers

3. Selected cross sections of the North Fork Toutle, Toutle, and Toutle River channeis utilized in modeling studies

4. Profiles of peak discharge along the Toutle River for Spirit Lake dam failure modeling study

5. Selected cross sections for the Cowlitz River valley utilized in model studies _-

\section{TABLES}

TABLE 1. Summary of peak discharges and elevations along the North Fork Toutle and Toutle Rivers for three assumed cases of the Spirit Lake debris-dam failure

2. Summary of peak discharges and elevations along the North Fork Toutle, Toutle, and Cowlitz Rivers for the CASE II Spirit Lake dam failure

Page

3. Comparison of discharge simulated by model runs with measured or estimated peak discharges on the North Fork Toutle and Toutle Rivers for the Elk Rock dam failure 

HYDROLOGIC EFFECTS OF THE ERUPTIONS OF

MOUNT ST. HELENS, WASHINGTON, 1980

\title{
EMERGENCY ASSESSMENT OF MOUNT ST. HELENS POST-ERUPTION FLOOD HAZARDS, TOUTLE AND COWLITZ RIVERS, WASHINGTON
}

\author{
By M. E. Jennings, V. R. Schneider, and P. E. SMITH
}

\begin{abstract}
Flood hazards created by natural dams on the Toutle and Cowlitz River systems formed from rock and debris deposits derived from the May 18, 1980, eruption of Mount St. Helens were analyzed and evaluated. The post-eruption structures investigated include the dam impounding Spirit Lake and the dam at Elk Rock on the North Fork Toutle River. Working under emergency conditions, efforts were made to adapt modeling programs to the unique drainage conditions confronted. Dam-break and flood-routing models utilized in the study are described.

The Elk Rock dam failed after the assessment was conducted. Computed peak discharge values were approximately the same as those measured or estimated during and following the failure.

The studies illustrate that useful dam-break and flood-hazard estimates are possible with existing computer models, even though data may be only approximate and incomplete.
\end{abstract}

\section{INTRODUCTION}

Mount St. Helens, in southwestern Washington, erupted at 8:32 a.m., P.s.t., on May 18, 1980. The north side of the volcano's cone was blown off by a powerful lateral blast, and a huge volume of debris buried land and water features in the drainage area immediately north and northwest of the mountain. Major geomorphic and hydrologic changes extended downstream along the Toutle and Cowlitz Rivers, with mudflows and hydraulic effects reaching the Columbia River (fig. 1). Details of these post-eruption events are described in other reports of this volume.

This report deals with emergency flood hazard situations created by the massive debris avalanche deposit in the North Fork Toutle River valley and by downstream sediment deposition. The debris deposit is up to $600 \mathrm{ft}$ thick; it formed a dam approximately $500 \mathrm{ft}$ high at the outlet of Spirit Lake, creating a set of conditions conducive to overtop- ping and subsequent downstream flooding. To date (March 1981), this has not occurred. However, Geological Survey hydrologists witnessed and recorded the overtopping and failure of a similar but smaller dam in the North Fork Toutle River near Elk Rock. A flood-hazard assessment made the day before the dam failure proved to be reasonably accurate and useful for the choice of advance protective measures.

The report contains (1) a brief description of the computer models employed to make the damfailure and flood-threat analyses; (2) analyses of the dam-failure potential at Spirit Lake and at Elk Rock; and (3) hypothetical flood routings from both of these sites.

\section{DAM-FAILURE HAZARD COMPUTER MODELS}

Modeling methods were employed in an effort to identify and compute the flood hazards associated with the massive post-eruption drainage modifications. Land (1980) described and evaluated available dam-failure, flood-wave computer models and concluded that the model developed by Fread (1980) was the most generally applicable. Land prepared a modified version, named the Dam Break Flood Forecast (DBFF) model, which was utilized for the Mount St. Helens dam-break hazard calculations.

The DBFF modification of Fread's model employs the current understanding of dam-failure mechanics and hydrodynamic flow theory to predict the formation of a dam-failure wave and its downstream movement. The modified model is a practical tool with wide applicability. It can function with input data ranging from complete and 


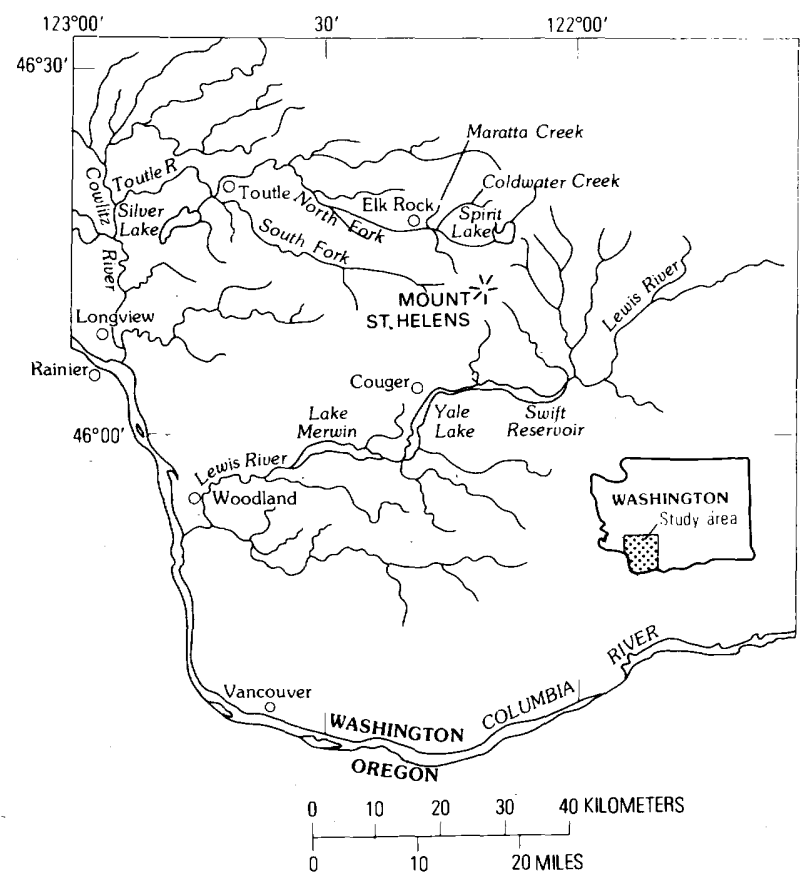

Figure 1.- The Mount St. Helens area.

accurate data specification to merely rough estimates of input parameters. The model is economical to run, requiring only nominal amounts of time on large computers.

The DBFF model consists of three functional parts (Fread, 1980; Land, 1980): (1) description of the mode of dam failure, that is, the temporal and geometrical description of the breach; (2) computation of the hydrograph of outflow through the developing breach as governed by the physical and hydraulic features of the reservoir, mainly rates of inflow to the reservoir and its storage characteristics; and (3) routing of the outflow hydrograph through the downstream valley to determine discharge hydrograph changes resulting from downstream variations in valley storage capacity and from frictional resistance to flow.

The DBFF model permits adoption of a variety of breach formation characteristics to simulate either overtopping or piping failure. The user specifies the failure time interval and the final size and shape of the fully developed breach. During model operation, the breach formation commences when the reservoir's water-surface elevation (h) exceeds a critical input stage $\left(h_{f}\right)$. An overtopping failure is simulated when $h_{f}$ is set to a value such that a sufficient amount of water is flowing over the crest of the dam to cause failure. A piping failure is simulated when $h_{\mathrm{f}}$ is set to a value below the height of the dam. Overtopping failure modes were assumed for the North Toutle River calculations. The mode of breach failure selected influences the results significantly.

DBFF computes the outflow from the breached dam as the summation of breach flow and flow through spillway outlets. The total outflow hydrograph is a function of water-surface elevation and outlet geometry and is related to depletion of reservoir storage volume. The reservoir routing in DBFF uses either (1) a hydrologic storage routing technique based on the law of conservation of mass; or (2) a hydraulic approach. The hydrologic storage routing technique was used for all reservoir routings described in this report.

After the outflow hydrograph from a breached dam is determined (expressed in terms of stage and discharge by the model), it is necessary to route the hydrograph through the downstream river valley. The DBFF model utilizes a hydraulic routing method based on the two differential equations governing one dimensional unsteady flow, the equations of continuity and momentum. A nonlinear implicit finite-difference algorithm was employed to solve the equations. The computational procedure is capable of simulating both subcritical and supercritical flows.

According to Fread (1980), a distinguishing feature of flood waves generated by dam failure is the great magnitude of the peak discharge compared to runoff-generated flood waves. A dam failure 
flood is usually many times greater than the runoff flood of record. For example, the most severe flood estimated for a Spirit Lake debris dam failure was about 25 times the maximum flood observed on the Toutle River during a 54-year period. The timespan from the first rise to the peak of the discharge hydrograph generally is very short. This feature can cause serious computational difficulties. In the process of routing dam-failure flood hydrographs down the North Fork Toutle and the Toutle Rivers, considerable time was spent eliminating computational problems introduced by the rapid rise in stage.

An unsteady streamflow simulation model, J879, documented by Land (1978) was used to route flood hydrographs down the North Fork Toutle River, and then down the Cowlitz River to its juncture with the Columbia River. J879 is a computer program for simulating one-dimensional subcritical, gradually varied unsteady flow. It does not perform dam-failure calculations. The program solves the differential equations for unsteady flow, using a linear implicit finite-difference algorithm as the computational method. Details of the J879 computational scheme are contained in a report by Land (1978). Model J879 was employed because the DBFF model did not include the option that would accommodate the correct downstream boundary condition at the Columbia River.

\section{SPIRIT LAKE DAM-FAILURE HAZARD}

Many uncertainties arose immediately following the eruption of Mount St. Helens concerning the extent of hazards, both geologic and hydrologic. The massive debris blockage-estimated to be 3 to 4 billion cubic yards (Youd and Wilson, 1980) - was known to block the outlet of Spirit Lake. However, due to poor visibility from aircraft and the dangers of onsite observation, only limited information was available on the size of the post-eruption lake and on the stability of the debris dam.

On May 19, Geological Survey hydrologists visited the area and determined that the elevation of the lake surface had been raised about $200 \mathrm{ft}$ by the events of May 18. It was thought that the lake represented a possible flood hazard, and the Survey thus initiated work to estimate the downstream flow peaks that would occur if the debris dam failed. The estimates were to be completed within 2 days and, therefore, based largely on initial field observations of water and land conditions. This input information was fragmentary and approximate, particulary for Spirit Lake storage characteristics and the debris dam.

Figure 2 compares an approximate debrismodified bed profile of the North Fork Toutle River compared to the originals bed profile. Figure 3 shows representative channel cross sections constructed from topographic maps and used in the modeling study for the North Fork Toutle and Toutle Rivers. Note the marked variation in channel cross-sectional shape. Although pre-eruption cross-sectional configuration was used in the absence of post-eruption information, vertical elevations of cross section in the first $14.5 \mathrm{mi}$ below the lake outlet were raised in accordance with early estimates of the debris-modified bed profile. The elevations adopted are somewhat lower than those given in the report by Youd and Wilson (1980, fig. 2).

The use of approximate cross-sectional information from small-scale maps was to prove a hindrance to acceptable computational results. The

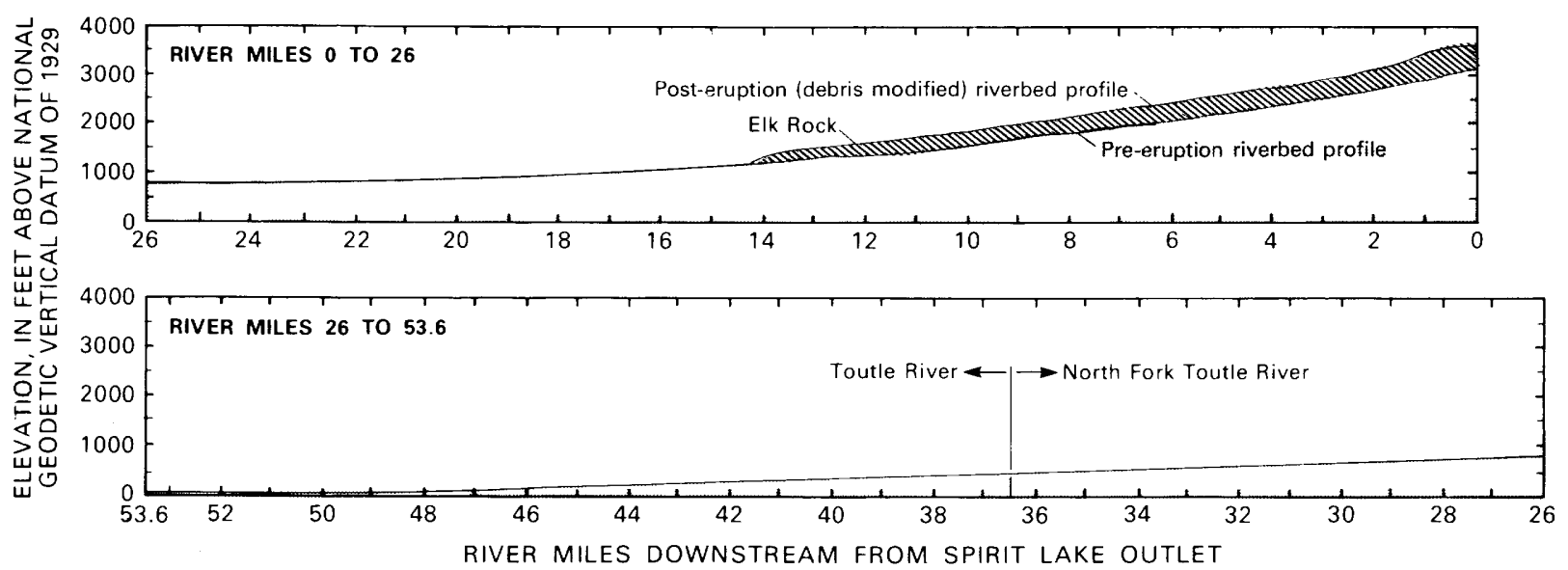

FIgURE 2. - Approximate pre- and post-eruption bed profiles of the North Fork Toutle and Toutle Rivers pre-, May 18, 1980, eruption. Spirit Lake outlet is at mile 0. Adapted from Youd and Wilson (1980, fig.2) 

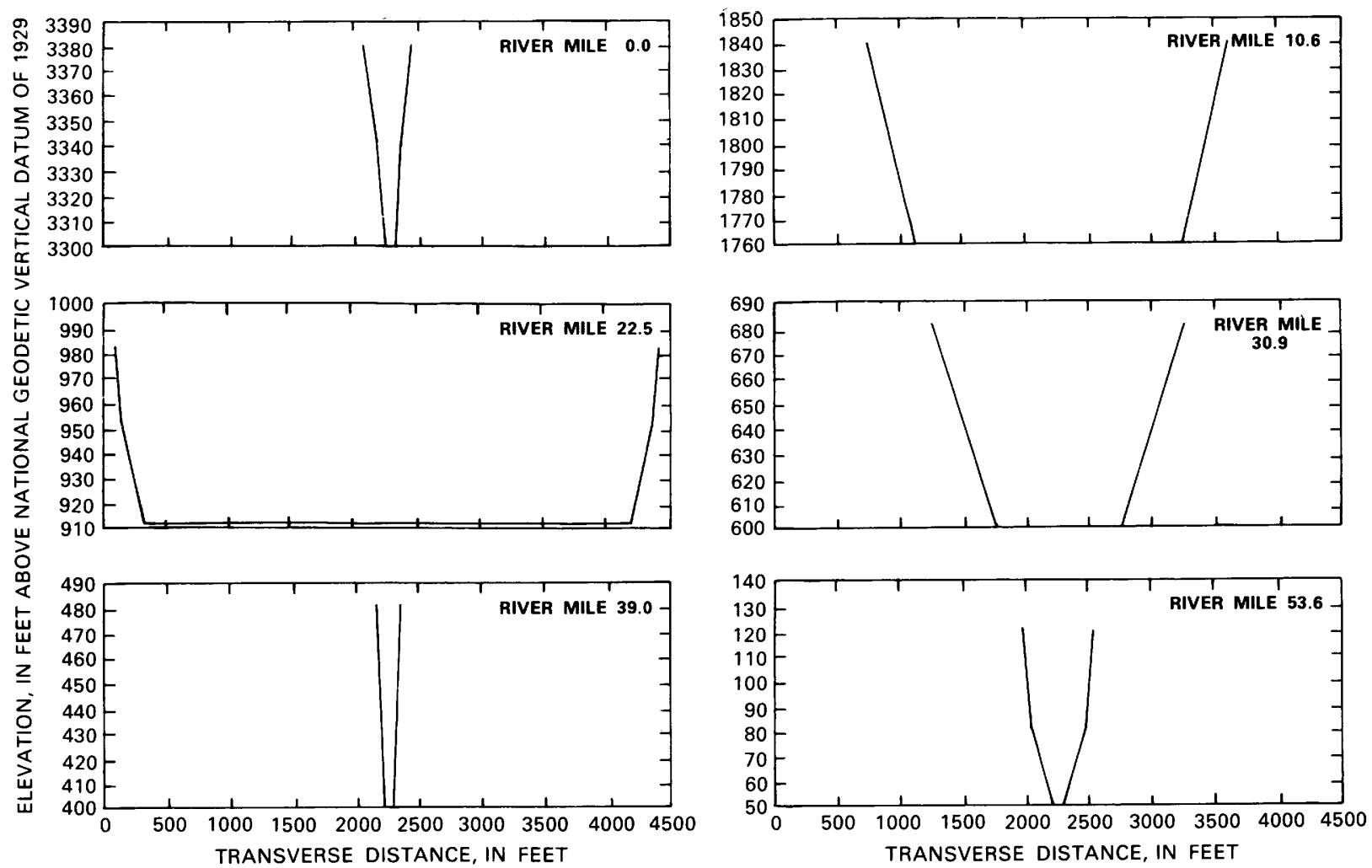

Figure 3.-Selected pre-, May 18, 1980, eruption cross sections of the North Fork Toutle, Toutle, and Toutle River channels utilized in modeling studies.

DBFF model computations failed to provide reasonable answers because the actual crosssectional shapes varied markedly in places from the idealized inputs used for the modeling exercise.

One of the many difficulties encountered in evaluation of the Spirit Lake flood hazard was determination of the most probable mode of failure of the Spirit Lake dam (Youd and Wilson, 1980). In addition to the stability of the debris material forming the dam, the probable mode of failure was dependent on the height and lateral width of the dam, the size and volume of the lake, and the height of water behind the dam. Field information was minimal. Attempts to treat the debris as a dam proved only partly useful. It was finally decided to conceptualize the Spirit Lake hazard as an overtopping, rather than a piping failure or other possible form of breach. Because of the great downstream extent of the debris (14.5 mi), piping or other forms of failure were considered unlikely.

Overtopping conceivably could result from mudflows entering the lake, from snow- and icemelt runoff, or a combination of these events. Water discharged by overtopping failure was visualized to flow over the debris and down the channels carved in the debris mass by the mudflow that followed the May 18 damming of Spirit Lake.
Working from this hypothesis of the mode of failure, calculations were made for overtopping and failure of the Spirit Lake dam throughout the estimated 53.6-mi reach from Spirit Lake (mi 0.0) to the mouth of the Toutle River (mi 53.6). A trapezoidal breach was adopted as the most probable geometric profile, and side slopes of 2 vertical to 1 horizontal were assumed. Three cases were investigated, assuming different sizes and durations of breach development:

CASE I-Duration of breach development equals $1 \mathrm{hr}$; final breach depth equals 150 $\mathrm{ft}$; maximum width of breach equals $200 \mathrm{ft}$; discharge at dam equals $1,130,000 \mathrm{ft}^{3} / \mathrm{s}$;

CASE II-Duration of breach development equals $1 \mathrm{hr}$; final breach depth equals 100 $\mathrm{ft}$; maximum breach width same as in CASE I; discharge at dam equals 613,000 $\mathrm{ft}^{3} / \mathrm{s}$;

CASE III-Duration of breach development equals $3 \mathrm{hr}$; final breach depth equals $50 \mathrm{ft}$; maximum breach width same as in CASE I; discharge at dam equals $174,000 \mathrm{ft}^{3} / \mathrm{s}$.

The discharges in each case were computed on the basis of estimated reservoir stage and the assumed breach dimensions. 


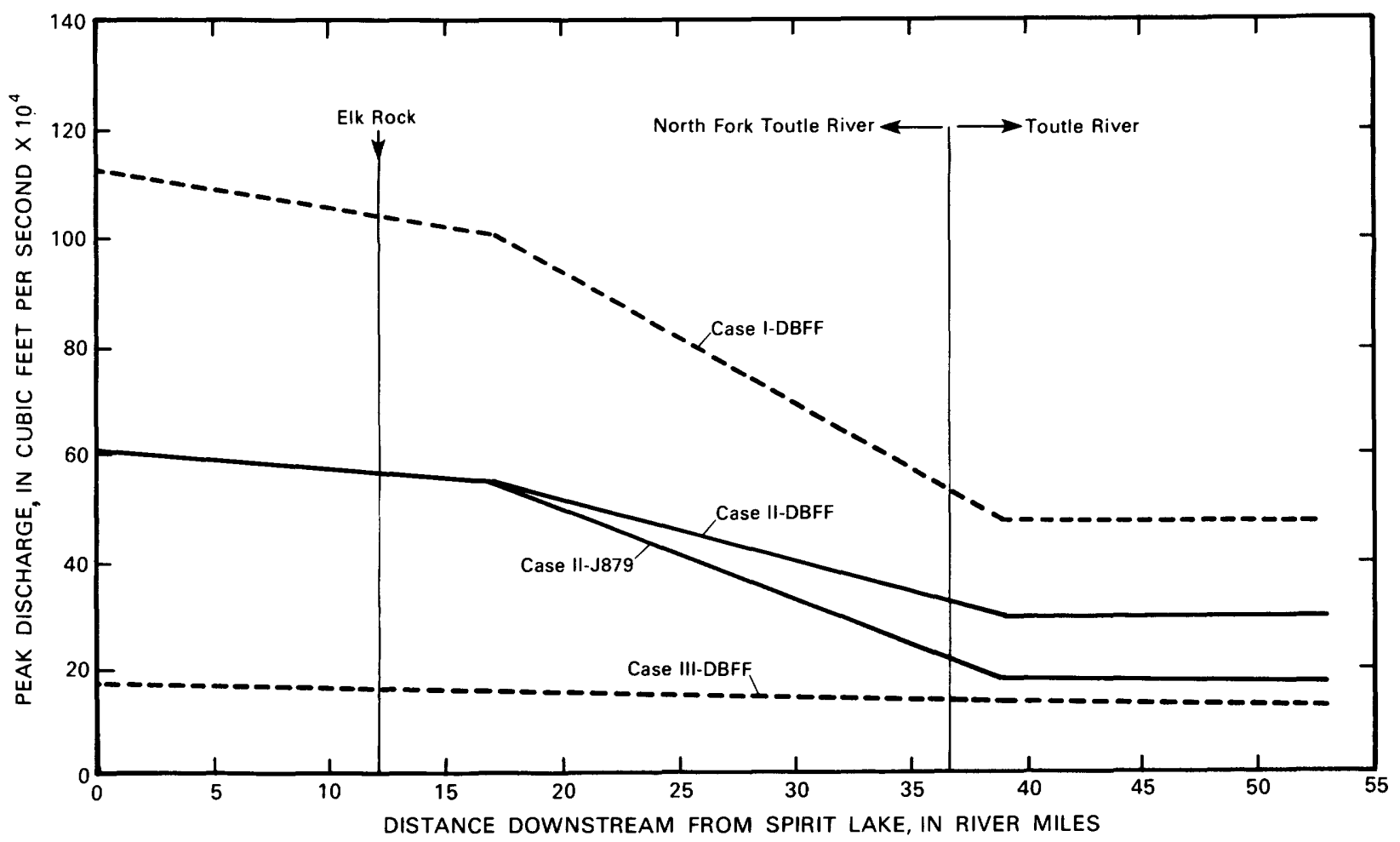

Figure 4.-Profiles of peak discharge along the Toutle River for Spirit Lake dam failure modeling study.

Results of calculations for the three cases are presented in table 1 and figure 4 . The computed range in downstream discharge was wide and convergence of profiles at the mouth was only moderate, indicating little attenuation of the flood wave. Thus, uncertainty in the prediction of potential failure characteristics resulted in corresponding uncertainty in the dam-failure flood-hazard estimates.

The CASE II results shown in table 1 were reported to Geological Survey headquarters as the basis for emergency planning. Subsequently, calculations were made for CASE II conditions in the Cowlitz River using the flood-routing program J879. A special river mileage system was adopted for the Cowlitz River flood-routing exercise and the calculations were based on the channel cross sections shown in figure 5. As for the North Fork Toutle and Toutle Rivers, no post-eruption data were available, necessitating the use of preeruption configurations. In addition, assumptions were made of a constant flow of $9,000 \mathrm{ft}^{3} / \mathrm{s}$ from the upper Cowlitz River and a constant Columbia River stage elevation at mile 73.1 (mouth of Cowlitz River) of $5.5 \mathrm{ft}$ above National Geodetic Vertical Datum (NGVD). The Columbia River at

TABLE 1.-Summary of peak discharges and elevations along the North Fork Toutle and Toutle Rivers for three assumed cases of Spirit Lake debris-dam failure (computed using the DBFF model)

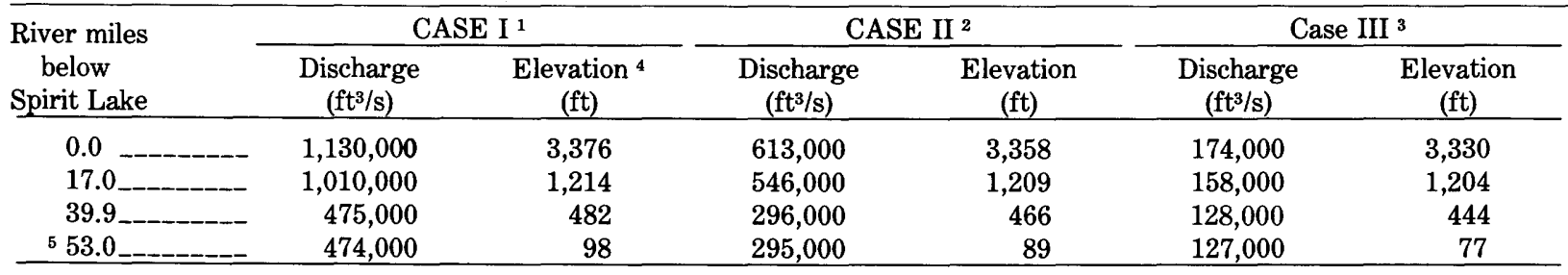

1 CASE I.-Duration of breach development equals $1 \mathrm{hr}$, terminal breach depth equals $150 \mathrm{ft}$, and the maximum width of the breach equals $200 \mathrm{ft}$.

${ }^{2}$ CASE II. - Duration of breach development equals $1 \mathrm{hr}$, terminal breach depth equals $100 \mathrm{ft}$, and the maximum width of the breach equals $200 \mathrm{ft}$.

${ }^{3} \mathrm{CASE}$ III. - Duration of breach development equals $3 \mathrm{hr}$, terminal breach depth equals $50 \mathrm{ft}$, and the maximum width of the breach equals $200 \mathrm{ft}$.

4 Elevations are referenced to National Geodetic Vertical Datum of 1929.

6 River mile 53.6 is the mouth of the Toutle River. 
TABLE 2.-Summary of peak discharges and elevations along the North Fork Toutle, Toutle, and Cowlitz Rivers for the CASE II Spirit Lake dam failure (computed using the J879 models)

\begin{tabular}{ccc}
\hline $\begin{array}{l}\text { River miles } \\
\text { below }\end{array}$ & \multicolumn{3}{c}{ CASE II } \\
\cline { 2 - 3 } Spirit Lake & $\begin{array}{c}\text { Discharge } \\
\left(\mathrm{ft}^{3} / \mathrm{s}\right)\end{array}$ & $\begin{array}{c}\text { Elevation }{ }^{1} \\
\text { (ft) }\end{array}$ \\
\hline 17.0 & 557,000 & 1,209 \\
39.0 & 176,000 & 450 \\
53.0 & 174,000 & 85 \\
$254.3------$ & 183,000 & 65 \\
63.4 & 138,000 & 36 \\
473.1 & 72,500 & 5.5 \\
\hline
\end{tabular}

${ }^{1}$ Elevations are referenced to National Geodetic Vertical Datum of 1929.

${ }^{2}$ River mile 54.3 is first cross section on Cowlitz River (fig. 5).

${ }^{3} \mathrm{~A}$ constant flow of $9,000 \mathrm{ft}^{3} / \mathrm{s}$ was assumed to come from the upper reach of the Cowlitz River.

${ }^{4}$ River mile 73.1 is the mouth of the Cowlitz River. The downstream boundary condition adopted was a constant water surface elevation of $5.5 \mathrm{ft}$.

this location is affected significantly by tides, but for simplification the average elevation was adopted.

The results of the calculations for CASE II, using J879, from mile 17.0 below Spirit Lake to mile 73.1 are given in table 2. The discharge estimate of $138,000 \mathrm{ft}^{3} / \mathrm{s}$ at mile 63.4 can be used as a point of context. This discharge corresponds to about a 500-year flood for an unsilted Cowlitz River channel. It is necessary to note, however, that sedimentation following mudflows on May 18-19 markedly reduced the floodwater capacity of the lower Cowlitz River.

A comparison of results obtained using DBFF and J879 was possible below mile 17 on the North Fork Toutle and Toutle Rivers. The flood routing technique in J879 gave considerably more attenuation than DBFF (fig. 4.). The explanation is not obvious and requires further research. It is possible that J879, at least for large, steep-fronted flood waves, may contain some artificial numerical attenuation, especially where reach sizes and time steps are large. The attenuation may be the result of using the linear implicit finite-difference algorithm. The attenuation of the flood wave yielded by the DBFF model was so small that it is somewhat questionable, especially in reaches of the Toutle River downstream from the junction of the North and South Forks.

\section{ELK ROCK DAM HAZARD}

The surface of the debris clogging in the North Fork Toutle River was highly hummocky, with many depressions and pits, some of which contained ponded water. The debris dammed the mouth of several tributaries of the North Fork, including Maratta and Coldwater Creeks. During Ju- ly and early August 1980, a small lake impounded at the mouth of Maratta Creek (fig. 1) broke through its dam as a result of saturation of the dam material and overtopping. The lake water flowed downstream a short distance where it became trapped behind an obstruction on the hummocky surface of the debris deposit. The obstruction soon failed and the water moved $4 \mathrm{mi}$ farther downstream, where it collected behind another obstruction, forming a 250 acre-foot lake near Elk Rock.

The new lake presented a flood hazard and the Geological Survey personnel, thus, made a series of dam-break calculations using DBFF and input data obtained from onsite observations. The dam was $112 \mathrm{ft}$ high and $215 \mathrm{ft}$ wide. The ponded water was $30 \mathrm{ft}$ deep, placing the pond surface $82 \mathrm{ft}$ above the base of the dam.

The model computations were made on August 26. The next day, the dam failed following a rainstorm. Over a period of several hours, Geological Survey personnel observed the breaching of the dam (which took about $40 \mathrm{~min}$ ) and the downstream movement of the flood wave.

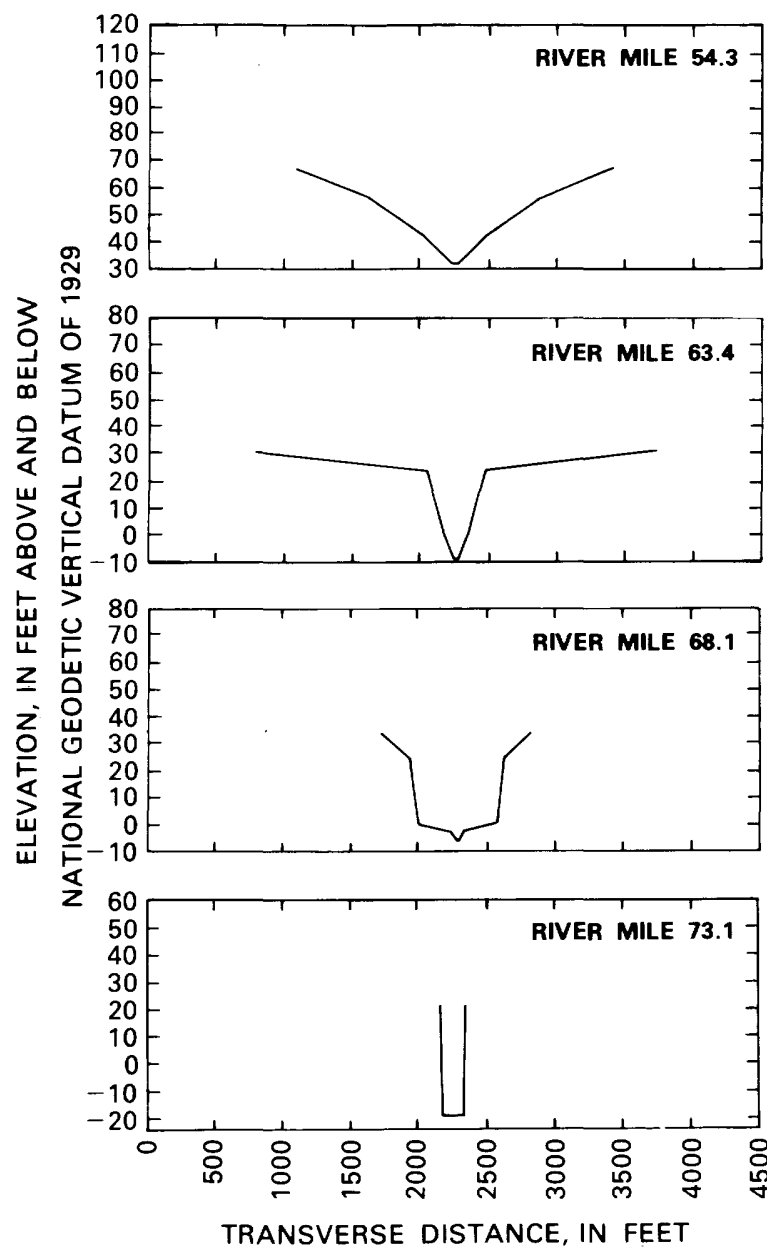

FIGURE 5.-Selected pre-, May 18, 1980, eruption cross sections for the Cowlitz River valley utilized in model studies. 
TABLE 3.-Comparison of discharge simulated by model runs with measured or estimated peak discharges on the North Fork Toutle and Toutle Rivers for the Elk Rock dam failure.

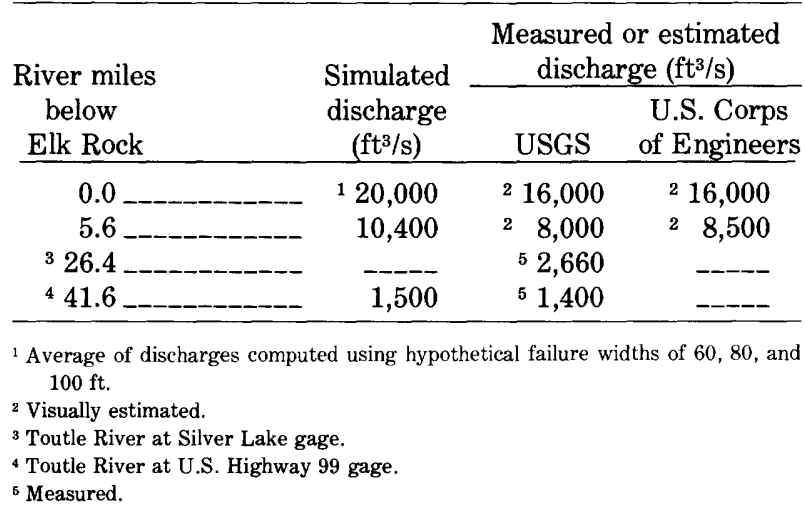

Visual estimates of flood discharge were made by Geological Survey and U.S. Corps of Engineers personnel at several locations, and discharge was measured at two gage sites. Table 3 compares the computed peak discharge at various locations with the estimated and measured peak discharges. The computed discharge at the dam was based on the assumed formation of a near-vertical 30 - $\mathrm{ft}$ slot ( 100 percent breach) in the 112-ft high and 215 -ft wide plug during a period of $0.1 \mathrm{hr}$. Calculations were made and results averaged using hypothetical failure widths of 60,80 , and $100 \mathrm{ft}$. The actual failure occurred progressively but erratically during $40 \mathrm{~min}$, and resulted in an irregular opening about $52 \mathrm{ft}$ high.

Considering the hypothetical assumptions on which the model calculations were based, the comparison between the simulated and the estimated/measured discharges is considered to be good.

The Elk Rock dam failure resulted in damage to channel-maintenance equipment in the North Fork Toutle River, but no loss of life or injuries were incurred. The success of the preevent prediction underscores the utility of computer-based models for estimating flood hazards resulting from dam breaks.

\section{CONCLUSIONS}

Flood hazards posed by potential dam failures were evaluated under hurried, emergency conditions in order to plan for and minimize dangers of flooding associated with the volcanic eruption and debris flow. Investigations included the debris pile impounding Spirit Lake and the dam formed at Elk Rock. The DBFF model was used to evaluate hypothetical failures and to route flows to the Cowlitz River. A second model (J879) was used to route flow down the Cowlitz to the Columbia River.
For both models, uneven levels of data accuracy and completeness hampered computation of reliable hazard estimates.

The Elk Rock dam failed the day following the theoretical failure analysis, providing an opportunity to compare hypothetical and actual results. The comparison between the simulated and estimated discharge is good, indicating that computer models can play a useful role in the assessment of dam-break flood hazards, even though input data are approximate and incomplete.

\section{REFERENCES}

Fread, D. L.,1976,Flood routing in meandering rivers with flood plains: Third Annual American Society of Civil Engineers, Rivers, '76, Symposium of Waterways, Harbors, and Coastal Engineering Division, August, Proceedings, v. I, p. 16-35.

-1980, DAMBRK: The NWS dam-break flood forecasting model: Silver Springs, Maryland, Office of Hydrology, National Weather Service (NWS) report, $37 \mathrm{p}$.

Land, L. F., 1978, Unsteady streamflow simulation using a linear implicit finite-difference model: U.S. Geological Survey Water Resources Investigations 78-59, $59 \mathrm{p}$. 1980, Evaluation of selected dam-break flood-wave models by using field data: U.S. Geological Survey Water Resources Investigations 80-44, $60 \mathrm{p}$.

Youd, T. L., and Wilson, Raymond, 1980, Stability of Toutle River blockage: Mount St. Helens hazard investigation: U.S. Geological Survey Open-File Report 80-898, 14 p. 


